\title{
Morphological and Biochemical Answer of the Wheat Seeds at Treatment with 2,4-Dinitrophenol and Potassium Iodate
}

\author{
Elena Todirascu-Ciornea $^{1 *}$, Gabi Drochioiu ${ }^{1}$, Raluca Stefanescu ${ }^{1}$, Elena Violeta Axinte ${ }^{2}$, \\ Gabriela Dumitru1. \\ ${ }^{I}$ Alexandru Ioan University, Biology Bvd. Carol I, Romania; ${ }^{2}$ Technological High School Petru Rares Botosani, \\ Romania.
}

\begin{abstract}
Oxidative stress can be regarded as an imbalance between the amount of reactive oxygen species (ROS) and the ability of a biological system to eliminate the toxic species and repair the resulting damages. Since the germinating seeds and the resulted seedlings are rich in enzymes, whereas the treatment with chemicals affects much the seed germination, producing also ROS, we evaluate here the influence of 2,4-dinitrophenol (DNP) and potassium iodate $\left(\mathrm{KIO}_{3}\right)$ on wheat germination (Triticum aestivum L.) and seedlings growth. Germination rate, the masses and heights of the 7 day old seedlings, as well as the activity of some enzymes involved in the oxidative stress such as peroxidase, catalase and superoxide dismutase were measured seven days after the chemical treatment.

The treatment of the wheat seeds with $10^{-5}-10^{-3} \mathrm{M}$ solutions of DNP resulted in a relative concentration-dependent inhibition of the germination, with a concomitant stimulation of the weight and height of viable seedlings. The Gasparom variety treated with $10^{-5} \mathrm{M} \mathrm{KIO}_{3}$ showed a slight increase in the germination rate in comparison with the control batch. The two tested substances determined a significantly modified response of the oxidative stress enzymes, especially in the seeds treated with $10^{-4}$ and $10^{-3} \mathrm{M}$ solutions.
\end{abstract}

Key words: DNP, $\mathrm{KIO}_{3}$, oxidative stress, wheat

\footnotetext{
${ }^{1}$ Authors for correspondence: ciornea@uaic.ro
} 


\section{INTRODUCTION}

Germination represents the complex process in which a new plant develops from a seed under the environmental conditions that determine the transformation of a mature quiescent seed into a germinating seed. From the physiological point of view, this process starts with the imbibitions of the seeds and ends with the protrusion of the radicle and plumule through the seed coat (Nath 1991). At the same time, Fercha et al. (2014) define the germination as the result of the interaction and crossed communication on multiple channels between the wheat grain embryo and the tissues and substances that surround it. A series of events occur when a viable seed, come-out from a lag period, imbibes with water: the hydration of cytoplasm associated with a massive structural reorganization of the membrane and cellular organelle, an accentuated increase of the seed respiration during the first hour of imbibition (that corresponds to the first phase of the germination) associated with a considerable mitochondrial differentiation and an increase in the ATP level (five times higher after 30 minutes from seed imbibition with water) (Morohashi et al. 1981 quoted by Nath 1991). After that take place a stabilization of this process or a moderate increase (the second phase of the germination process), until the radicle emerges at the surface, phenomenon that completes the germination process (Al-Ani et al. 1985). The mitochondrion is the first site where the energy is produced and the first source of endogenous oxygen reactive species a slight uncoupling of the oxidative phosphorylation being one of the mechanisms through which the production of oxygen radicals is controlled by the mitochondrion (Skulacev 2004).

The release of inorganic phosphorus and the cellular energy increases together with the intensification of the respiration that plays a very important role in the production of energy which is essential for the normal development of the metabolic process during germination. After that, new proteins, nucleic acids and lipids are synthesized and reserve substances are used as nutrients for the growing seedling (Burzo et al. 1999). The development and maturation of the wheat grain occurs in stages that have their own features (Phillipe et al. 2006; Chen et al. 2012).

There are more than 250 proteins in the endosperm of mature seeds that participate during the germination in 13 biochemical processes, such as reactions of ATP interconversion (Weitbrecht et al. 2011), carbohydrate metabolism (Aoki et al. 2006), cell division, the formation of cellular cytoskeleton, nitrogen metabolism (Mayer and Poljakoff-Mayber 1982; Pate and Layzell 1990), lipid metabolism, the synthesis of aminoacids and proteins and their assembly (Mayer and Poljakoff-Mayber 1982; Lea et al. 1990), protein turnover, signal transduction, protein storage, the implication in different stress types and cellular defense against these, signal transcription, translation and transport (Vensel et al. 2005). Among the 250 proteins, 207 of them are located in the peripheral layers of the wheat grain (inner pericarp, hyaline layer, testa and aleurone layer) (Tasleem-Tahir et al. 2011), the site where the proteases act intensively during germination. The 13 biochemical processes associated with the germination implicate 51 genes which play a central role (Yu et al. 2014).

The environmental agents such as many pollutants caused by the intensive application of different substances such as insecticides, pesticides and fungicides play an important role in the process of plant development. Therefore, the present study aims to evaluate the influence of different concentrations of 2,4-dinitrophenol and potassium iodate on seed germination and seedling growth. Wheat seeds, Triticum aestivum L., Putna and Gasparom varieties, were investigated and the activity of oxidative stress enzymes was determined in 7 day old seedlings.

\section{MATERIALS AND METHODS}

All the reagents used were of analytic purity and were purchased from Sigma-Aldrich (Steinheim, Germany; Saint Louis, Missouri) and Merck (Darmstadt, Germany). The solutions were prepared with MilliQ-grade water $(18.2 \mathrm{M} \Omega \cdot \mathrm{cm})$. The UV-vis measurements were performed using a Shimadzu UV-VIS 1700 spectrophotometer, in quartz cuvettes with a path length of $1 \mathrm{~cm}$ against the control carried out only with the reagents.

\section{Wheat Seeds Germination}

Two seed varieties, Putna and Gasparom, harvested in 2013 were taken from the Suceava Genebank, Romania. Batches of 50 seeds were treated with water (control) or $10^{-3}, 10^{-4}$ and $10^{-5} \mathrm{M}$ solutions of 2,4-dinitrophenol (DNP) and potassium iodate 
$\left(\mathrm{KIO}_{3}\right)$ for one hour. All the treatments were performed in triplicate. Following the treatment, the seeds from each batch were uniformly distributed in $9 \mathrm{~cm}$ diameter Petri dishes on double layer of filter paper together with $2 \mathrm{ml}$ of the treatment solution. Then, the Petri dishes were covered with their lids, and $2 \mathrm{~mL}-5 \mathrm{~mL}$ of distilled water were added to maintain the seeds wet.

\section{Seedling Growth Measurements}

The germination rate was calculated for each Petri dish after counting the number of seedlings, the number of non-viable caryopses or the sprouted ones, which did not grow. The total weight (expressed as grams) of the seedlings from each Petri dish was determined, followed by the calculation of the average value per seedling. The height (expressed as $\mathrm{cm}$ ) of each seedling was measured and the average value was calculated.

\section{Determination of Enzyme Activity}

To determine the activity of superoxide dismutase (SOD), catalase (CAT) and peroxidase (POX), the stem and leaves were separated from the roots and the seminal initial material subjected to germination.

SOD (E.C. 1.15.1.1) activity was determined by the method proposed by Winterbourn et al. (1975) and modified by Artenie et al. (2008). The method measures the capacity of the enzyme to inhibit the reduction of Nitro Blue Tetrazolium by the superoxide radicals produced by the photochemical reduction of riboflavin $(\lambda=560 \mathrm{~nm})$.

CAT (E.C. 1.11.1.6) activity was measured using the method of Sinha (Artenie et al. 2008). According to this method, the absorbance of chromic acetate obtained in the reaction of potassium dichromate reduction under acidic environment by hydrogen peroxide found in excess after the inactivation of the enzyme was measured at $\lambda=570 \mathrm{~nm}$.

POX (EC 1.11.1.7) activity was determined using the method of Gudkova and Degtiari (1969), quoted by Artenie et al. (2008). According to this method, the o-dianisidine is allowed to react with hydrogen peroxide and peroxidase and the colour intensity of the oxidised product of o-dianisidine is measured at $540 \mathrm{~nm}$.

The total soluble protein concentration was obtained using the Bradford method (Bradford 1976; Artenie et al. 2008) with bovine serum albumin as standard.

\section{Statistical Analysis}

The results were statistically analyzed using the SPSS20 program (the mean value, the standard deviation and the limits of the confidence interval) and Microsoft Excel (t-Student test) the results being considered significant at $p$ values smaller than 0.05 (Hinton et al. 2004).

\section{RESULTS}

The identification of the effects of 2,4dinitrophenol (DNP), which is known to affect the oxidative phosphorylation in mitochondria, used in different concentrations $\left(10^{-3}, 10^{-4}, 10^{-5} \mathrm{M}\right)$ on the germination of the wheat seeds was the first goal of our study. At the same time other lots of seeds were treated with the strong oxidizing compound $\mathrm{KIO}_{3}$ using the same concentrations, since we did not find scientific data regarding the effects of this substance on the germination of Triticum seeds.

\section{Seedling growth}

In the last years, in agricultural practices it is used the available organic sources for to increase the crop production and to soil fertilization (Herridge et al. 1995 cited by Pandiaraj et al. 2015).

Dinitrophenols, azides, fluorides and other chemicals can be metabolic inhibitors if used at certain concentrations, but their action on the metabolic processes may be different (Mayer and Poljakoff-Mayber 1982). Dinitrophenol and its related esters proved their eficiencies as pesticides, insecticides, ovicides, acaricides, fungicides, and herbicides due to their multiple biological actions (Mwesigwa et al. 2000; Volkov and Mwesigwa 2001). Since high concentrations of DNP are toxic due to uncoupling the respiration from the oxidative phosphorylation (ATP synthesis), we expect a stimulatory effect on germination of the very low concentrated solutions of this compound (Zaharia et al. 2014; Dumitraş-Huţanu et al. 2009; Drochioiu 2010).

In the first experiments, we calculated the germination rate of the caryopses of the two varieties of wheat for each treatment made. Figure 1 shows the average of the three values of each batch. The seeds of the Putna variety displayed the germination rate between 90 and $94 \%$ (the average $92 \%$ and the confidence range of \pm 2.263 ), while the Gasparom variety had a lower germination rate of only $82 \%$ (the confidence range was between 80 and $84 \%)$. 


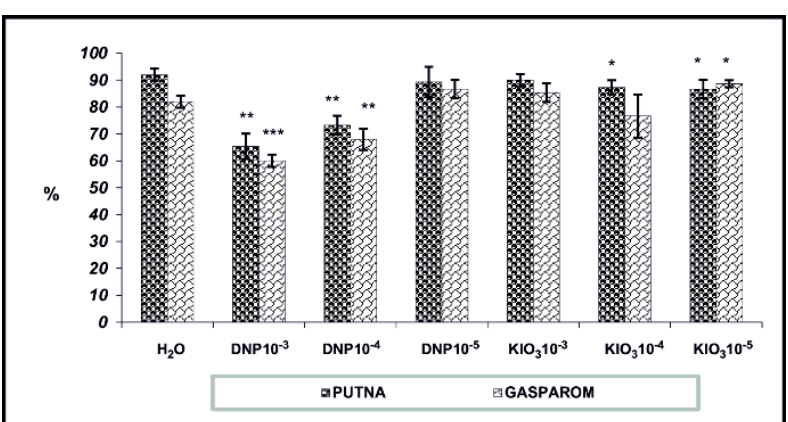

Figure 1 - The germination rate of wheat seeds treated with DNP and KIO3***p $<0.001$ (very significant); ** $0.001<\mathrm{p}<0.005$ (moderate significant); $* 0.01<\mathrm{p}<0.05$ (significant); $0.05<\mathrm{p}<0.5$ (not significant)

These results that show a slightly lower germination rate of the wheat seeds could be explained if we consider the fact that the process of seed deterioration begins immediately after the harvest and there are diverse internal and external agents that contribute to the deterioration (Patil et al. 2004). However, we introduced old seeds of Gasparom wheat since we are interested in the stimulation of the germination of cereal seeds conserved in gene banks.

Remarkable differences were noticed between the batches treated with DNP solutions and the control ones as well as between the different concentrations of the same chemical. Thus, the $10^{-3}$ and $10^{-4} \mathrm{M}$ DNP significantly decreased the germination rate of both Putna variety (65\% and $73 \%$, respectively) and Gasparom one (60\% and 68\%). The $10^{-5} \mathrm{M}$ DNP did not significantly influence the germination rate as compared with the control batch (the Putna variety showed a germination rate of $89 \%$, whereas the Gasparom one, $87 \%$ ). In the case of the treatment with $10^{-4} \mathrm{M}$ DNP, the germination rate of both wheat varieties was statistically different from the reference value $(0.001<\mathrm{p}<0.005)$.

Our results confirm too that DNP, even at relatively high concentrations, stimulates the phenomenon of output seeds from the biological repose period, observing that even the mean germinative faculty per batch decreased, the number of germinated caryopses, but unviable is higher comparatively with those ungerminated, report to the control batch. Thus, the Putna seeds treated with water generated seedlings, germinated but did not grow, and did not germinate in the following proportion $92 \%: 2.67 \%: 5.33 \%$. At the same seeds treated with DNP $10^{-3} \mathrm{M}$ the proportion was $65.33 \%$ : $23.33 \%$ : $11.34 \%$. The germination rate of Gasparom seeds treated with DNP $10^{-3} \mathrm{M}$ was $60 \%$ with a confidence interval of \pm 2.3 , in comparison with the control batch where the germination rate was $82 \% \pm 2.27$ (21\% germinated seeds that did not grow and $19 \%$ unsprouted seeds in comparison with 8 and $10 \%$ respectively). The statistical analysis highlighted that $10^{-3} \mathrm{M}$ DNP exerts a significant influence on the germination of the Gasparom seeds $(\mathrm{p}<0.001)$.

Potassium iodate did not significantly influence the germination rate of the wheat seeds. However, the seeds of Gasparom variety treated with a $10^{-5} \mathrm{M}$ solution of $\mathrm{KIO}_{3}$ were slightly stimulated $(87 \% \pm$ 1.3 versus $82 \% \pm 2.3$, in the case of control).

The treatment of Putna wheat seeds with the $10^{-3} \mathrm{M}$ solution of DNP resulted in 7 day old seedlings with an average mass of $0.0521 \mathrm{~g} / \mathrm{seedling}$, whereas that of the control was $0.0543 \mathrm{~g} / \mathrm{seedling}$ (Figure 2), whereas the same treatment applied to Gasparom seeds produced seedlings with an average mass of $0.0441 \mathrm{~g}$ (Control, $0.0356 \mathrm{~g}$ ). The $10^{-3} \mathrm{M} \mathrm{KIO}_{3}$ solution reduced the mass of Putna seedlings, but increased that of the Gasparom ones (0.047 $\mathrm{g} /$ seedling versus $0.0356 \mathrm{~g} / \mathrm{seedling}$ ).

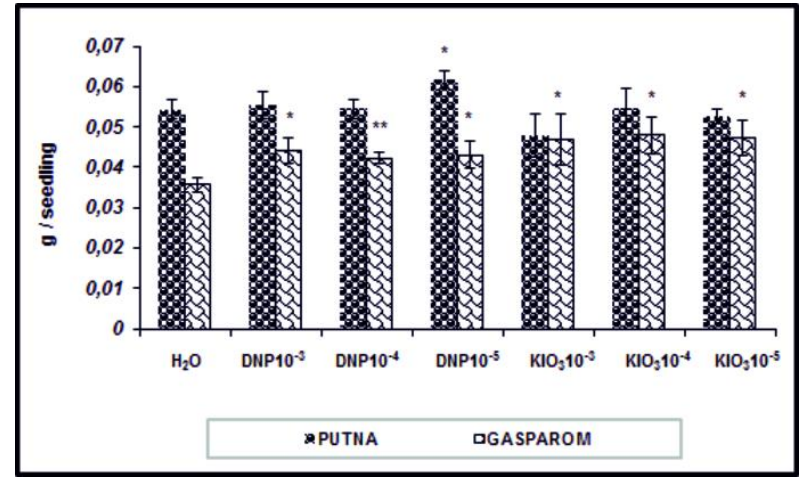

Figure 2. Average mass of the seedlings resulted in the treatment of the two varieties of wheat seeds with DNP and $\mathrm{KIO}^{*} * * \mathrm{p}<0.001$ (very significant); ** $0.001<\mathrm{p}<0.005$ (moderate significant); $* 0.01<\mathrm{p}<0.05$ (significant); $0.05<\mathrm{p}<0.5$ (not significant)

The height of the seedlings from the treatment with $10^{-3} \mathrm{M}$ DNP was $9.4 \mathrm{~cm} /$ seedling, being decreased in comparison with the control batch (10.2 $\mathrm{cm} /$ seedling). The Gasparom seedlings were $7.3 \mathrm{~cm}$ in height (control) and $8.5 \mathrm{~cm}\left(10^{-3} \mathrm{M} \mathrm{DNP}\right)$, respectively (Figure 3). 


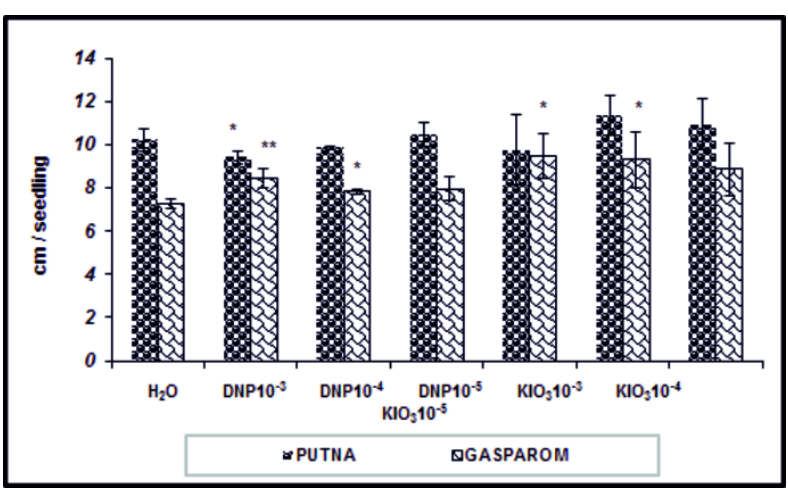

Figure 3 - The effect of DNP and KIO3 on the average height of the 7 day old wheat seedlings $* * *$ p $<0.001$ (very significant); $* * \quad 0.001<\mathrm{p}<0.005 \quad$ (moderate significant); * $0.01<\mathrm{p}<0.05$ (significant); $0.05<\mathrm{p}<0.5$ (not significant)

The $10^{-3} \mathrm{M} \mathrm{KIO}_{3}$-treated Gasparom seeds produced $9.4 \mathrm{~cm}$ seedlings (Control, $7.3 \mathrm{~cm}$ ), whereas the same treatment on Putna seeds resulted in $11.4 \mathrm{~cm}$ height seedlings.

The statistical analysis of the experimental results showed the moderate significant influence of $10^{-4}$ M DNP on the weight of the seedlings from the Gasparom variety and of the $10^{-3} \mathrm{M}$ DNP on the extension of the same seedlings $(0.001<\mathrm{p}<0.005)$.

\section{Biochemical results}

Some authors introduced the concept of "oxidative window for germination" since there is a critical level of ROS associated with the germination (Bailly et al. 2008). The implications of the changes in the redox state at Triticum are in direct correlation with the process of germination in wheat and the antioxidant sensitivity during the development of the seedlings (Isibashi et al. 2012; Inada et al. 2012). Generally, the superoxide dismutase activity was higher in both wheat varieties (Figure 4) treated with DNP in comparison with the seedlings from the control batch (Putna variety: $7.61 \pm 0.93 \mathrm{USOD} / \mu \mathrm{g}$ protein; Gasparom variety: $7.75 \pm 0.496 \mathrm{USOD} / \mu \mathrm{g}$ protein). The maximum value for SOD was obtained in the treatment with $10^{-4} \mathrm{M}$ DNP on both Putna variety $(10.91 \pm 0.75 \mathrm{USOD} / \mu \mathrm{g}$ protein, with the confidence interval between 9.445 and 10.943 $\mathrm{USOD} / \mu \mathrm{g}$ protein) and Gasparom variety (9.64 \pm $0.67 \mathrm{USOD} / \mu \mathrm{g}$ protein, the confidence interval of the average having a minimum of $8.962 \mathrm{USOD} / \mu \mathrm{g}$ protein and a maximum of $10.312 \mathrm{USOD} / \mu \mathrm{g}$ protein). Such increase in the SOD activity following the DNP treatment may be associated with the intensification of the removing the superoxide radicals formed under the influence of DNP.

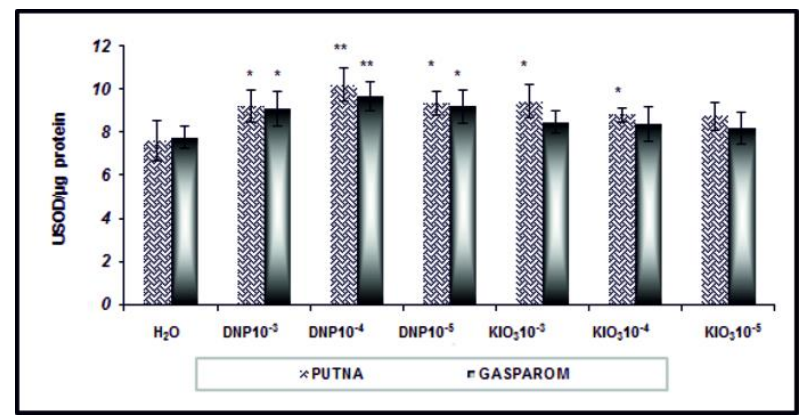

Figure 4 - The activity of superoxide dismutase at two wheat varieties subjected to germination in the laboratory after a treatment with DNP and KIO3***p < 0.001 (very significant); $* * 0.001<\mathrm{p}<0.005$ (moderate significant); $* 0.01<\mathrm{p}<0.05$ (significant); $0.05<\mathrm{p}<0.5$ (not significant)

$\mathrm{KIO}_{3}$ did not significantly influence the activity of SOD (control batch: about $7.7 \mathrm{USOD} / \mu \mathrm{g}$ protein in both varieties). The maximum value was recorded for the treatment with $10^{-3} \mathrm{M} \mathrm{KIO}_{3}$ on the Putna seeds $(9.43 \pm 0.76 \mathrm{USOD} / \mu \mathrm{g}$ protein) and on the Gasparom ones $(8.18 \pm 0.77 \mathrm{USOD} / \mu \mathrm{g}$ protein for $10^{-5} \mathrm{M} \mathrm{KIO}_{3}$, and $8.46 \pm 0.52 \mathrm{USOD} / \mu \mathrm{g}$ protein for $10^{-3} \mathrm{M} \mathrm{KIO}_{3}$ ). The small difference recorded for the SOD activity between the control batch and the treated batches indicated that potassium iodate does not induce an overproduction of superoxide radicals.

Catalase, which intervenes in the antioxidant defense system next to the peroxidase by decomposing the hydrogen peroxide, behaved similarly to peroxidase in seedlings (Figure 5).

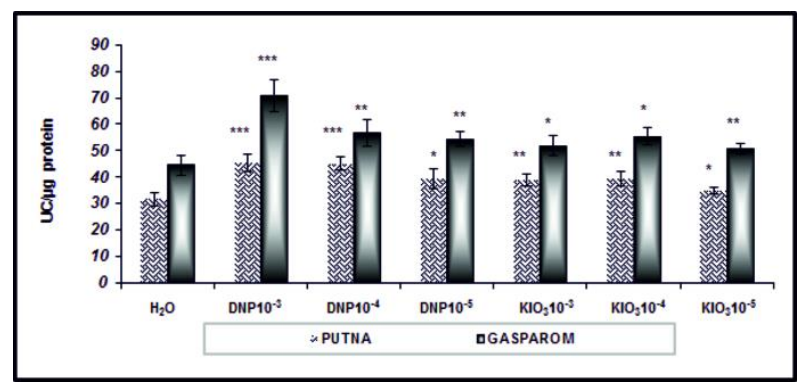

Figure 5 - The influence of DNP and KIO3 on the catalase activity of wheat seedlings $* * * p<0.001$ (very significant); $* * 0.001<\mathrm{p}<0.005$ (moderate significant); $* \quad 0.01<\mathrm{p}<0.05 \quad$ (significant); $0.05 \quad<\mathrm{p}<0.5 \quad$ (not significant)

Catalase activity in Putna seedlings was $45.33 \pm$ $3.09 \mathrm{UC} / \mu \mathrm{g}$ of protein when treated with $10^{-3} \mathrm{M}$ $\mathrm{DNP}, \quad 45.02 \pm 2.49 \mathrm{UC} / \mu \mathrm{g}$ of protein at a 
concentration of $10^{-4} \mathrm{M}$ DNP, and $39.49 \pm 3.80$ $\mathrm{UC} / \mu \mathrm{g}$ of protein, respectively, for the $10^{-5} \mathrm{M}$ DNP treatment solution. The Gasparom seedling displayed a higher catalase activity as compared with the Putna variety, as well as with the control batch $(44.35 \pm 3.61 \mathrm{UC} / \mu \mathrm{g}$ protein). The maximum value was observed in the case of $10^{-3} \mathrm{M}$ DNP $(70.92 \pm 5.97 \mathrm{UC} / \mu \mathrm{g}$ protein) and the minimum one $(54.34 \pm 2.84 \mathrm{UC} / \mu \mathrm{g}$ protein) for the treatment with $10^{-5} \mathrm{M}$ DNP solution. Consequently, 2,4dinitrophenol increased catalase activity in a concentration-dependent manner.

In the evaluation of the catalase activity one has to consider the fact that the seedlings were obtained by germination in the laboratory, all the plants being treated daily with the same volume of water but they grew under various light conditions (natural light, artificial light and dark) and fluctuating temperature. It is known the fact that the stress produced by the abiotic factors is able of inducing in the wheat caryopses that are in the process of germination the modulation of glutathione activity an important endogenous antioxidant and this is capable of influencing the peroxidase activity that catalyzes the reduction of the oxidized glutathione (Chen et al. 2013) and to increase the activity of catalase (Yang et al. 2002).

The exposure of the wheat caryopses to solutions of $\mathrm{KIO}_{3}$ was associated with significant modifications of the antioxidant enzyme activity that suggest complex interactions between the germinating seed metabolism and agents that generate oxygen reactive species. Thus, $\mathrm{KIO}_{3}$ also induced the accumulation of hydrogen peroxide in Triticum aestivum caryopses, which required a higher level of catalase activity in comparison with the control batch $(31.49 \pm 2.40 \mathrm{UC} / \mu \mathrm{g}$ protein in Putna control seedlings, $44.35 \pm 3.61 \mathrm{UC} / \mu \mathrm{g}$ protein for the Gasparom ones). The highest activity was determined at both varieties in the case of the $10^{-4}$ $\mathrm{M} \mathrm{KIO}_{3}$ solution $(39.26 \pm 2.20 \mathrm{UC} / \mu \mathrm{g}$ protein for Putna variety, and $55.41 \pm 3.23 \mathrm{UC} / \mu \mathrm{g}$ protein for Gasparom one). Catalase and peroxidase may play very important role in the first phase of the seedling growth because they remove the hydrogen peroxide produced during the $\beta$-oxidation of the fatty acids (Bailly 2004) in the seeds with a high content of lipids (Costin 1983 quoted by Hodişan and Timar 2010).

The catalase activity was significantly influenced ( $\mathrm{p}$ $<0.001$ ) by the $10^{-3} \mathrm{M}$ DNP solution, whereas the batches treated with $\mathrm{KIO}_{3}$ suffered a significant influence $(0.01<p<0.05)$ or moderate significant $(0.001<\mathrm{p}<0.005)$ as a function of the concentration used.

The peroxidase activity in wheat seedlings treated with DNP was found increased in both Putna and Gasparom seedlings (Figure 6), being 18.65 UP/ $\mu \mathrm{g}$ protein (with a confidence of \pm 1.29 ) for the treatment with $10^{-4} \mathrm{M}$ DNP of Putna seeds, 13.21 $\mathrm{UP} / \mu \mathrm{g}$ protein (with a confidence of \pm 1.697 ) for that with $10^{-3} \mathrm{M}$ DNP of Gasparom seeds $(8.83 \pm 1.12 \mathrm{UP} / \mu \mathrm{g}$ protein for Putna control, and $5.19 \pm 0.92 \mathrm{UP} / \mu \mathrm{g}$ protein for Gasparom control).

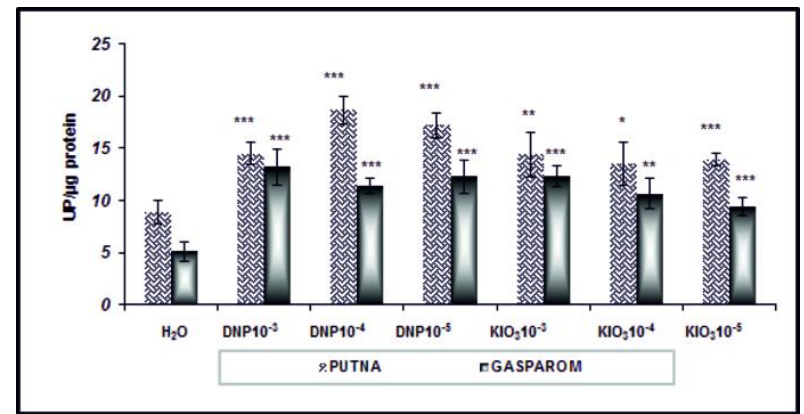

Figure 6 - The effect of DNP and KIO3 on the peroxidase activity of wheat seedlings $* * * p<0.001$ (very significant); $* * 0.001<\mathrm{p}<0.005$ (moderate significant); * $\quad 0.01<\mathrm{p}<0.05 \quad$ (significant); $0.05 \quad<\mathrm{p}<0.5 \quad$ (not significant)

The increased activity of the peroxidase in caryopses can be considered as an efficient growth signature, the enzyme being involved in the control of cellular activity (Afify Abd El-Moneim et al. 2012).

It is known the fact that the application of different treatments during seed storage is slowing significantly their deterioration rate and increases fast the viability rate of the seeds. Thus, halogens such as chlorine, bromine or iodine are used in formulas in which they can act on unsaturated fatty acids and stabilize the lipid membrane by controlling the free radical production acting either as scavengers or as extinguishers of free radicals. According to some authors, iodine (and other halogens) has the capacity to stabilize the double bond carbon-carbon and reduces the peroxidation and the generation of reactive oxygen species (Hunje et al. 2007).

In the case of $10^{-3} \mathrm{M} \mathrm{KIO}_{3}$ treatments of Putna and Gasparom seeds, the values for peroxidase activity were $14.44 \pm 2.14 \mathrm{UP} / \mu \mathrm{g}$ protein and $12.30 \pm 0.98$ $\mathrm{UP} / \mu \mathrm{g}$ protein, respectively, whereas the control values were $8.83 \mathrm{UP} / \mu \mathrm{g}$ protein and $5.13 \mathrm{UP} / \mu \mathrm{g}$ protein. 
The interpretation of the data obtained after the application of the t-Student test supports the idea that the influence of DNP and $\mathrm{KIO}_{3}$ on the activity of peroxidase is detectable, the values of $\mathrm{p}$ being very significant $(\mathrm{p}<0.001)$.

\section{DISCUSSION}

It is known that adaptive response of plants to the action of various natural edaphic factors, but also the human factor, that have marked influences on the germination, growth and development processes of plant organisms (Nayyar and Gupta 2006). Literature data highlights the negative effect of pesticides, insecticides, fungicides used increasingly in recent years in agriculture (Mwesigwa et al. 2000; Volkov and Mwesigwa 2001), the presence of various heavy metals in the soil as a result of mining activities (Donkor et al. 2005), the level of rainfall (Hosseini et al. 2015), and soil maintenance practices (Kumar et al. 2013). Our results regarding the effect of DNP on the germination rate are in agreement with those found in literature (Hollingworth 2001; Drochioiu et al. 2009; Al-Mutairi 2010; Huțanu et al. 2013; Todirascu-Ciornea and Dumitru 2015). There are no measurements to prove that the germination process is modified in a different way in comparison with other stages of growth, differentiation and development. However, Murariu and Drochioiu (2012) showed that DNP has toxic effects on the germination of Triticum even at low concentrations, being able to affect the biostructural level of the eucariotic organisms. Moreover, the related compounds have similar effects even if they do not possess any free $-\mathrm{OH}$ group able to determine a $\mathrm{H}^{+}$gradient through the biological membranes (Dumitras-Huţanu et al. 2008; 2009).

In fact, any substance that is capable to influence the metabolism of the germinating seed may induce significant changes in the subsequent development of the plant according to the types of substances, their concentration and toxicity (Vojtechova and Leblova 1991; Xiong 1998). In this regard, Nosko et al. (1988) reported that differently concentrated solutions of aluminum ions do not inhibit the germination rate of the seeds of Picea glauca but modify their viability. Peralta et al. (2001) showed that $\mathrm{Cr}, \mathrm{Cu}, \mathrm{Cd}, \mathrm{Ni}$, and $\mathrm{Zn}$ ions reduce the germination rate of the Medicago sativa $\mathrm{L}$. seeds as well as the size of the radicles and tigellas of the resulted seedlings. Munzuroglu and Geckil (2002) studied the influence of metal ions such as $\mathrm{Hg}^{2+}$, $\mathrm{Cd}^{2+}, \mathrm{Co}^{2+}, \mathrm{Cu}^{2+}, \mathrm{Pb}^{2+}$ and $\mathrm{Zn}^{2+}$ on the germination of Triticum aestivum and Cucumis sativum seeds and highlighted the inhibition of this process depending on the concentration and the reduction of the length of both radicle, hypocotyls and coleoptile of the seedlings.

In contrast with our observations, the experiments carried out by Huţanu et al. (2013) in the concentration range from $10^{-4} \mathrm{M}$ to $10^{-2} \mathrm{M}$ DNP demonstrated the strong toxicity of $3 \times 10^{-3} \mathrm{M}$ concentration of 2,4-dinitrophenol on the wheat seeds. Even at a concentration of $3 \times 10^{-4} \mathrm{M}$, DNP inhibits the germination of wheat seeds (the germination rate $87 \%$ ). Yu et al. (1980) showed that DNP is able to inhibit the ethylene biosynthesis, a compound implicated in seed germination, since it activates some enzymes. Indeed, at higher concentrations than $3 \times 10^{-3} \mathrm{M}$, DNP completely inhibited seed germination.

Our data are in agreement with other authors (Cakmak et al. 1993) that suggest that the enzyme activity of POX, CAT, SOD and GPX (glutathione peroxidase) increases during the germination of seeds, and, especially, during the emergence of the radicles (Kang and Saltveit 2002). Indeed, after 2448 hours from the imbibition, the increase in enzyme activities is much higher in the embryo than in the endosperm, whereas the SOD activity increases less after 72 hours in comparison with other enzymes (Dučić et al. 2003/4; Prodanović et al. 2007).

The intensification of the activity of peroxidase and catalase indicates $10^{-5} \mathrm{M}-10^{-3} \mathrm{M}$ DNP is able to induce a significant uncoupling of the electron transport chain and of the oxidative phosphorylation, resulting in the dissipation of the membrane gradient and in the increase in the production of ROS.

Certainly the much higher activity of the peroxidase from the experimental batches is caused by treatment with 2,4-dinitrophenol and it can be associated with an intervention in lignification, suberization (the peroxidase is implicated in the polymerization of the aromatic monomers), auxins catabolism, in the processes of germination and growth of seedlings. According to some authors (Øestergaard et al. 2000; Schopfer 2001; Passardi et al. 2005; Diaz-Tiaels et al. 2012; Zhang et al. 2014) it can be associated with a high number of metabolic processes such as cellular elongation and lignification, phenolic oxidation, defense against stress represented by different pathogens and 
abiotic stress this enzyme playing an important role in seed germination, in the processes of growth and morphogenesis, modifications of this oxidoreductase occurring during modulation of the cellular differentiation processes and tissue development (Kawano 2003).

The increase in the peroxidase activity measured in our experiments is in agreement with data collected in tomato seeds (Morohashi 2002), which demonstrated hydrogen peroxide formation and a decrease in NADH production in the endosperm before the emergence of the radicles. Halliwell (1978) also showed that DNP and $\mathrm{Mn}^{2+}$ ions act as cofactors that intensify the oxidation of $\mathrm{NADH}$, in a reaction catalyzed by peroxidase. Maeder and Amberg-Fisher (1982) quoted by Morohashi (2002) reported the same reaction in tobacco seeds. Hydrogen peroxide intensifies the germination rate in wheat seeds being produced at the beginning of the imbibition with water and is eliminated when it is in excess by catalase and ascorbat peroxidase (Ishibashi et al. 2008). Wong et al. (2004), Cazalis et al. (2006), Pulido et al. (2009), reported that the antioxidant redox system in wheat grain plays a central role in the germination and development of the seedlings. Other data from the scientific literature indicate the existence of other enzyme systems and non-enzyme systems involved in the control of the oxidative balance by reducing the production of oxygen reactive species such as thiamine that is contained by the wheat in high amounts (Brandolini and Hidalgo 2012, Kanazawa et al. 2000 cited by Ali et al. 2015). This is capable of protecting the vegetal cell against various factors of abiotic stress by decreasing the protein carbonylation and the accumulation of hydrogen peroxide (Lozinsky et al. 2013). Considering the very high level of the catalase one can state that the intensification of the activity of this oxidoreductase is caused by the influence of 2,4-dinitrophenol.

\section{CONCLUSIONS}

The administration of DNP and $\mathrm{KIO}_{3}$ solutions to the caryopses of Triticum aestivum, Putna and Gasparom varieties, induced the accumulation of free oxygen radicals as demonstrated by the activity of oxidative stress enzymes, which was higher in all experimental batches in comparison with the control batch.

DNP demonstrated high toxicity by inhibiting the germination rate of the seeds especially at the concentrations of $10^{-4}$ and $10^{-3} \mathrm{M}$, while potassium iodate did not influence the germination or slightly stimulated the Gasparom seed germination only at low concentration of $\left(10^{-5} \mathrm{M} \mathrm{KIO}_{3}\right.$ where the germination rate was $87 \%$ in comparison with $82 \%$ in the control batch).

Although the germination process was negatively influenced by DNP and $\mathrm{KIO}_{3}$ an increase in the height and weight of the viable seedlings was observed. Such studies may be of interest for the investigators of the viability of cereal seeds conserved in gene banks, since the activity of the enzymes involved in the oxidative stress decreases with the storage time. Moreover, our investigation suggests the complexity of interaction between environmental compounds and the biochemical processes of germination.

\section{ACKNOWLEDGMENTS}

\section{Romanian Government (UEFISCDI Contract IDEI 313/2011).}

\section{REFERENCES}

Afify Abd El-Moneim MR, El-Beltagi HS, Aly AA, ElAnsary AE. Antioxidant enzyme activities and lipid peroxidation as biomarker for potato tuber stored by two essential oils from Caraway and Clove and its main component carvone and eugenol. Asian Pac J Trop Biomed. 2012; S772-S780.

Al-Ani A, Bruzau F, Raymond P, Saint-Ges V, Leblanc JM, Pradet A. Germination, respiration and adenylate energy charge of seeds at various oxygen partial pressures. Plant Physiol. 1985; 79: 885-890.

Ali B, Deng X, Hu X, Gill RA, Ali S, Wang S, Zhou W. Deteriorative effects of cadmium stress on antioxidant system and cellular structure in germinating seeds of Brassica napus L. J Agr Sci Tech. 2015; 17: 63-74.

Al-Mutairi NZ. 2,4-Dinitrophenol adsorption by date seeds: Effect of physico-chemical environment and regeneration study. Desalination. 2010; 250: 892-901.

Aoki N, Scofield GN, Wang XD, Offler CE, Patrick JW, Furbank RT. Pathway of sugar transport in germinating wheat seeds. Plant Physiol. 2006; 141 (4): 1255-1263.

Artenie Vl, Ungureanu E, Negură AM. Metode de investigare a metabolismului glucidic şi lipidic. Iaşi: Ed. Pim; 2008, 182p.

Bailly C. Active oxygen species and antioxidants in Seed Biology. Seed Sci Res. 2004; 14: 93-107.

Bailly C, El-Maarouf-Bouteau H, Corbineau F. From intracellular signaling networks to cell death: the dual role of reactive oxygen species in seed physiology. $C$ R Biol. 2008; 331 (10): 806-814. 
Bradford MM. A rapid and sensitive method for the quantitation of microgram quantities of protein utilizing the principle of protein dye binding. Anal Biochem. 1976; 72: 248-254.

Brandolini A, Hidalgo A. Wheat germs. Not only a byproduct. Int J Food Sci Nutr. 2012; 63 (1): 71-74.

Burzo I, Toma S, Crăciun C, Voican V, Dobrescu A, Delian E. Fiziologia plantelor de cultură, Volum I Procesele fiziologice din plantele de cultură, Chişinău: Întrep. Editorial - Poligrafică Ştiinţa; 1999.

Cakmak I, Strbac D, Marschner H. Activities of Hydrogen Peroxide-Scavenging Enzymes in Germinating Wheat Seeds. J Exp Bot. 1993; 44: 127132.

Cazalis R, Pulido P, Aussenac T, Pérez-Ruiz JM, Cejudo FJ. Cloning and characterization of three thioredoxin $h$ isoforms from wheat showing differential expression in seeds. J Exp Bot. 2006; 57: 2165-2172.

Chen Y, Zhang J, Xie P, Zhou W, Chen J, Wei C. Programmed cell death in wheat starchy endosperm during kernel development. Afr J Agric Res. 2012; 7 : 6533-6540.

Chen YP, Liu Q, Yue XZ, Meng ZW, Liang J. Ultrasonic vibration seeds showed improved resistance to cadmium and lead in wheat seedling. Environ Sci Pollut R. 2013; 20 (7): 4807-4816.

Díaz-Tiaels C, Graña E, Reigosa JM, Sánchez-Moreiras MA. The role of peroxidases on the mode of action of chalcone in Arabidopsis roots. Plant Signaling \& Behavior. 2012; 7: 1274-1276.

Donkor AK, Bonzongo JCJ, Nartey VK, Adotey DK. Heavy metals in sediments of the gold mining impacted Pra River basin, Ghana, West Africa. Soil Sed Contam. 2005; 14 (6): 479-503.

Drochioiu G, Dumitraş-Huțanu CA, Pal C, Pui A, Gradinaru RV, Pintilie O, et al. Effect of some pesticide dinitrophenols and other dinitrophenyl derivatives on wheat seed germination. Lucr Şt, USAMV Iași, Seria Horticultură. 2009; 52: 9-14.

Drochioiu G. Laser-induced ATP formation: Mechanism and consequences. Photomed Laser Surg. 2010; 28: 573-574.

Dučić T, Lirić-Rajlić I, Mitrović A, Radotić K. Activities of antioxidant systems during germination of Chenopodium rubrum seeds. Biol Plantarum. 2003/4; 47 (4): 527-533.

Dumitraş-Huţanu CA, Pui A, Grădinaru R, Drochioiu G. Toxicity of Dinitrophenyl derivatives used as pesticides and their environmental impact Revagrois, Lucr. Şt. USAMV Iaşi, Seria Agronomie. 2008; 51: 2934.

Dumitraş-Huţanu CA, Pui A, Jurcoane Ş, Rusu E, Drochioiu G. Biological effect and the toxicity mechanisms of some dinitrophenyl ethers. Rom Biotech Lett. 2009; 14 (6): 4893-4899.

Fercha A, Capriotti AL, Caruso G, Cavaliere C, Samperi $\mathrm{R}$, Stampachiacchiere S, et al. Comparative analysis of metabolic proteome variation in ascorbate-primed and unprimed wheat seeds during germination under salt stress. J Proteomics. 2014; 108: 238-257.

Halliwell B. Lignin synthesis: the generation of hydrogen peroxide and superoxide by horseradish peroxidase and its stimulation by manganese (II) and phenols. Planta. 1978; 140: 81-88.

Hinton PR, Brownlow C, McMurray I, Cozens B. SPSS explained. New York, USA: Routledge Taylor \& Francis Group; 2004.

Hodişan N, Timar A. Materii prime vegetale. Condiţionarea, păstrarea şi expertiza calităţii. Oradea: Ed. Univ. Oradea; 2010.

Hollingworth RM. Inhibitors and Uncouplers of Mitocondrial Oxidative Phosphorilation, In Krieger R. et al. editors. Handbook of Pesticide Toxicology Principles: Academic Press, 2001; p. 1169-1262

Hosseini SM, Hasanloo T, Mohammadi S. Physiological characteristics, antioxidant enzyme activities, and gene expression in 2 spring canola (Brassica napus L.) cultivars under drought stress conditions. Turk J Agric For. 2015; 39: 413-420.

Hunje R, Viakarnahal BS, Jagadeesh RC. Studies on halogenation and plant bi-products on storability of chilli seed. Karnataka J Agric Sci. 2007; 20: 506-510.

Huţanu CA, Zaharia M, Pintilie O. Quenching of tryptophan fluorescence in the presence of 2,4-DNP, 2,6-DNP, 2,4-DNA and DNOC and their mechanism of toxicity. Molecules. 2013; 18: 2266-2280.

Inada H, Kondo T, Akhtar N, Hoshino D, Yamaguchi M, Izuta T.. Relationship between cultivar difference in the sensitivity of net photosynthesis to ozone and reactive oxygen species scavenging system in Japanese winter wheat (Triticum aestivum). Physiol Plantarum. 2012; 146 (2): 217-227.

Ishibashi Y, Koda Y, Zheng SH, Yuasa T, Iwaya-Inoue M. Regulation of soybean seed germination through ethylene production in response to reactive oxygen species. Ann Bot-London. 2012; 111: 95-102.

Kang HM, Saltveit EM. Reduced chilling tolerance in elongating cucumber seedling radicles is related to their reduced antioxidant enzyme and DPPH-radical scavenging activity. Physiol Plantarum. 2002; 115: 244-250

Kawano T. Roles of the reactive oxygen speciesgenerating peroxidase reactions in plant defense and growth induction. Plant Cell Rep. 2003; 21: 829-837.

Kumar S, Chaudhuri S, Maiti SK. Soil dehydrogenase enzyme activity. In Natural and mine soil - a review. Middle East J Sci Res. 2013; 13: 898-906.

Lea JP, Robinson AS, Stewart RG. The enzymology and metabolism of glutamine, glutamate and asparagine (Chapter 4). In Miflin BJ, Lea JP, editors. Intermediary nitrogen metabolism (Volume 16), In Stumpf PK, Conn EE, editors. The biochemistry of plants. A comprehensive treatise. California: Academic Press, Inc. San Diego; 1990. p. 129-147.

Lozinsky VO, Lushchak OV, Storey MJ, Storey BK, Lushchak IV. The mitochondrial uncoupler 2,4- 
dinitrophenol attenuates sodium nitroprusside-induced toxicity in Drosophila melanogaster: Potential involvement of free radicals. Comp Biochem Physiol. 2013; 158: 244-252.

Mayer AM, Poljakoff-Mayber A. The germination of seeds (Third Edition). Great Britain: Pergamon Press; 1982.

Morohashi Y. Peroxidase activity develops in the micropylar endosperm of tomato seeds prior to radicle protrusion. J Exp Bot. 2002; 53: 1643-1650.

Munzuroglu O, Geckil H. Effects of metals on seed germination, root elongation, and coleoptile and hypocotyl growth in Triticum aestivum and Cucumis sativus. Arch Environ Con Tox. 2002; 43: 203-213.

Murariu M, Drochioiu G. Biostructural theory of the living systems. BioSystems. 2012; 109: 126-132.

Mwesigwa J, Collins DJ, Volkov AG. Electrochemical signaling in green plants: effects of 2,4-dinitrophenol on variation and action potentials in soybean. Bioelectrochemistry. 2000; 51 (2): 201-205.

Nath S. Changes in germination performance and hydrolytic enzyme activity in wheat seeds (Triticum aestivum L.) caused by ageing and pre-sowing treatments, PhD, Massey University, Palmerston North, New Zealand; 1991.

Nayyar H, Gupta D. Differential sensitivity of $\mathrm{C}_{3}$ and $\mathrm{C}_{4}$ plants to water deficit stress: association with oxidative stress and antioxidants. Environ Exp Bot. 2006; 58: 106-113.

Nosko P, Brassard P, Kramer JR, Kershaw KA. The effect of aluminum on seed germination and early seedling establishment, growth, and respiration of white spruce (Picea glauca). Can J Botany. 1988; 66: 2305-2310.

Østergaard L, Teilum K, Mirza O, Mattsson O, Petersen M, Welinder GK, et al. Arabidopsis ATP A2 peroxidase. Expression and high resolution structure of a plant peroxidase with implications for lignification. Plant Mol Biol. 2000; 44: 231-243.

Pandiaraj T, Selvaraj S, Ramu N. Effects of crop residue management and nitrogen fertilizer on soil nitrogen and carbon content and productivity of wheat (Triticum aestivum L.) in two cropping systems, J Agr Sci Tech. 2015; 17: 249-260.

Passardi F, Cosio C, Penel C, Dunand C. Peroxidases have more functions than a Swiss army knife. Plant Cell Rep. 2005; 24: 255-265.

Pate SJ, Layzell BD. Energetics and biological costs of nitrogen assimilation (Chapter 1), In Miflin BJ, Lea JP, editors. Intermediary nitrogen metabolism (Volume 16), In Stumpf PK, Conn EE, editors. The biochemistry of plants. A comprehensive treatise. California: Academic Press, Inc. San Diego; 1990. p. 27-31.

Patil S, Deshpande VK, Vyakarnahal BS, Krishna A, Kumar V, Hilli JS. Halogenation in sunflower with iodine and chloride. Karnataka J Agric Sci. 2004; 17 (4): 817-818.
Peralta JR, Gardea-Torresdey JL, Tiemann KJ, Gomez E, Arteaga S, Rascon E. et al. Uptake and effects of five heavy metals on seed germination and plant growth in alfalfa (Medicago sativa L.). B Environ Contam Tox. 2001; 66: 727-734.

Philippe S, Robert P, Barron C, Saulnier L, Guillon F. Deposition of cell wall polysaccharides in wheat endosperm during grain development: Fourier transform-infrared microspectroscopy study. $J \mathrm{Agr}$ Food Chem. 2006; 54 (6): 2303-2308.

Prodanović O, Prodanović R, Bogdanović J, Mitrović A, Milosavić N, Radotić K. Antioxidative enzymes during germination of two lines of serbian spruce [Picea omorika (Panć) purkyné]. Arch Biol Sci. 2007; 59 (3): 209-216.

Pulido P, Cazalis R, Cejudo FJ. An antioxidant redox system in the nucleus of wheat seed cells suffering oxidative stress. Plant J. 2009; 57: 132-145.

Schopfer P. Hydroxyl radical-induced cell-wall loosening in vitro and in vivo: implications for the control of elongation growth. Plant J. 2001; 28: 679688.

Skulachev VP. Mitochondria, reactive oxygen species and longevity: some lesson from the Barja group. Aging cell. 2004; 3: 17-19.

Tasleem-Tahir A, Nadaud I, Girousse C, Martre P, Marion D, Branlard G. Proteomic analysis of peripheral layers during wheat (Triticum aestivum L.) grain development. Proteomics. 2011; 11 (3): 371379.

Todirascu-Ciornea E, Dumitru G. Effect of 2,4dinitrophenol and potassium iodate on wheat germination. Int J Latest Research Technol. 2015; 4: 93-100.

Vensel WH, Tanaka CK, Cai N, Wong JH, Buchanan BB, Hurkman WJ. Developmental changes in the metabolic protein profiles of wheat endosperm. Proteomics. 2005; 5: 1594-1611.

Vojtechova M, Leblova S. Uptake of lead and cadmium by maize seedlings and the effects of heavy metals on the activity of phosphoenolpyruvate carboxilase isolated from maize. Biol Plantarum. 1991; 33: 386394.

Volkov GA, Mwesigwa J. Electrochemistry of soybean: effects of uncouplers, pollutants, and pesticides. $J$ Electroanal Chem. 2001; 496: 153-157.

Weitbrecht K, Müller K, Leubner-Metzger G. First off the mark: early seed germination. J Exp Bot. 2011; 62: 3289-3309.

Wong JH, Cai N, Tanaka CK, Vensel WH, Hurkman WJ, Buchanan BB. Thioredoxin reduction alters the solubility of proteins of wheat starchy endosperm: an early event in cereal germination. Plant Cell Physiol. 2004; 45: 407-415.

Yang Z, Bin W, Zhenzhen L. Effect of glutathione on ageing wheat seeds. J Liaoning Univ (Natural Sci Ed). 2002; 29 (3): 275-278. 
Yu YB, Adams DO, Yang SF. Inhibition of ethylene production by 2,4-dinitrophenol and high temperature. Plant Physiol. 1980; 66: 286-290.

Yu Y, Guo G, Lv D, Hu Y, Li J, Li X, et al. Transcriptome analysis during seed germination of elite Chinese bread wheat cultivar Jimai 20. BMC Plant Biol. 2014; 14: 20.

Xiong ZT. Lead uptake and effects on seed germination and plant growth in a $\mathrm{Pb}$ hyperaccumulator Brassica pekinensis Rupr. B Environ Contam Tox. 1998; 60: 285-291.
Zaharia M, Borhan A, Gherca D, Pui A, Gradinaru R, Zbancioc G, et al. Letter: Study on the mechanism of ferrite-induced dinitrophenol photodegradation. Eur J Mass Spectrom. 2014; 20: 193-197.

Zhang Y, Chen B, Xu Z, Shi Z, Chen S, Huang X, et al. Involvement of reactive oxygen species in endosperm cap weakening and embryo elongation growth during lettuce seed germination. J Exp Bot. 2014; 65: 31893200 .

Received: Setember 25, 2015; Accepted: April 05, 2016. 